more than two hours previously. The management of young children is more difficult-most episodes are poison scares rather than true poisonings. Rather than give young children charcoal immediately on presentation, we suggest confining it to the few who develop symptoms - in a dose sufficient to increase elimination of the drug.

Repeated doses of oral activated charcoal have not yet been shown to reduce morbidity and mortality. Further studies are required to establish its place and the dose to be given. Until these data are available, severely poisoned adults should be given $150-200 \mathrm{~g}$ through a nasogastric tube over 4-8 hours with the aims of achieving a maximum reduction in elimination half life and an improvement in the clinical state. The total dose given is probably more important than the frequency of dosing.

J A VALE

Director

National Poisons Information Service (Birmingham Centre),

West Midlands Poisons Unit,

Dudley Road Hospital,

Birmingham B18 7QH

A T PROUDFOOT

Director

National Poisons Information Service (Edinburgh Centre),

Scottish Poisons Information Bureau,

Royal Infirmary, Edinburgh EH3 9YW

1 Neuvonen PJ, Vartiainen M, Tokola O. Comparison of activated charcoal and ipecac syrup in prevention of drug absorption. Eur 7 Clin Pharmacol 1983;24:557-62.

2 Danel V, Henry JA, Glucksman E. Activated charcoal, emesis, and gastric lavage in aspirin overdose. BMF 1988;296:1507.

3 Scolding N, Ward MJ, Hutchings A, Routledge PA. Charcoal and isoniazid pharmacokinetics. Human Toxicology 1986;5:285-6.

4 Olkkola KT, Neuvonen PJ. Do gastric contents modify antidotal efficacy of oral activated charcoal? Brf Clin Pharmacol 1984;18:663-9.

5 Tenenbein M, Cohen S, Sitar DS. Efficacy of ipecac-induced emesis, orogastric lavage, and activated charcoal for acute drug overdose. Ann Emerg Med 1987;16:838-41

6 Neuvonen PJ, Elfving SM, Elonen E. Reduction of absorption of digoxin, phenytoin and aspirin by activated charcoal in man. Eur f Clin Pharmacol 1978;13:213-8.

Curtis RA, Barone J, Giacona N. Efficacy of ipecac and activated charcoal/cathartic: prevention of salicylate absorption in a simulated overdose. Arch Interm Med 1984;144:48-52.
Neuvonen PJ, Elonen E. Effect of activated charcoal on absorption and elimination of phenobarbitone, carbamazepine and phenylbutazone in man. Eur f Clin Pharmacol 1980;17: $51-7$

Scheinin M, Virtanen R, Iisalo E. Effect of single and repeated doses of activated charcoal on the pharmacokinetics of doxepin. Int f Clin Pharm Ther Toxicol 1985;23:38-42.

10 El-Bahie N, Allen EM, Williams J, Routledge PA. The effect of activated charcoal and hyoscine butylbromide alone and in combination on the absorption of mefenamic acid. $\mathrm{Br} \mathrm{f}$ Clin Pharmacol 1985;19:836-8.

11 NcNamara RM, Aaron CK, Gemborys M, Davidheiser S. Efficacy of charcoal cathartic versus ipecac in reducing serum acetaminophen in a simulated overdose. Ann Emerg Med 1989;18 934-8.

12 Lim DT, Singh P, Nourtsis S, Cruz RD. Absorption inhibition and enhancement of elimination of sustained-release theophylline tablets by oral activated charcoal. Ann Emerg Med 1986;15: 1303-7.

13 Neuvonen PJ, Olkkola KT. Activated charcoal and syrup of ipecac in prevention of cimetidine and pindolol absorption in man after administration of metoclopramide as an antiemetic agent. Clin Toxicol 1984;22:103-1

14 Cordonnier J, Van den Heede M, Heyndrickx A. Activated charcoal and ipecac syrup in prevention of tilidine absorption in man. Vet Hum Toxicol 1987;29(suppl 2):105-6.

15 Underhill TJ, Greene MK, Dove AF. A comparison of the efficacy of gastric lavage, ipecacuanha and activated charcoal in the emergency management of paracetamol overdose. Arch Emerg Med 1990;7:148-54.

16 Swartz CM, Sherman A. The treatment of tricyclic antidepressant overdose with repeated charcoal. f Clin Psychopharmacol 1984;4:336-40.

17 Neuvonen PJ, Elonen E, Mattila MJ. Oral activated charcoal and dapsone elimination. Clin Pharmacol Ther 1980;27:823-7.

18 Lalonde RL, Deshpande R, Hamilton PP, McLean WM, Greenway DC. Acceleration of digoxin clearance by activated charcoal. Clin Pharmacol Ther 1985;37:367-71.

19 Pond S, Jacobs M, Marks J, Garner J, Goldschlager N, Hansen D. Treatment of digitoxin overdose with oral activated charcoal. Lancet $1981 ;$ ii:1177-8.

20 Mauro LS, Mauro VF, Brown DL, Somaru P. Enhancement of phenytoin elimination by multipledose activated charcoal. Ann Emerg Med 1987;16:1132-5.

21 Ilkhanipour K, Yealy DM, Krenzelok EP. The comparative efficacy of various multiple-dose activated charcoal regimens. Am f Emerg Med 1992;10:298-300.

22 Goldberg MJ, Park GD, Spector R, Fischer LJ, Feldman RD. Lack of effect of oral activated charcoal on imipramine clearance. Clin Pharmacol Ther 1985; 38:350-3.

23 Mayer AL, Sitar DS, Tenenbein M. Multiple-dose charcoal and whole-bowel irrigation do not increase clearance of absorbed salicylate. Arch Intern Med 1992;152:393-6.

24 Boldy DAR, Heath A, Ruddock S, Vale JA, Prescott LF. Repeated oral activated charcoal in the treatment of carbamazepine poisoning. Lancet 1987; ;:1027.

25 Neuvonen PJ, Elonen E, Haapanen EJ. Acute dapsone intoxication: clinical findings and effect of oral charcoal and haemodialysis on dapsone elimination. Acta Med Scand 1983;214:215-20.

26 Boldy DAR, Smart V, Vale JA. Multiple doses of charcoal in digoxin poisoning. Lance 1985;ii:1076-7.

27 Boldy DAR, Vale JA, Prescott LF. Treatment of phenobarbitone poisoning with repeated ora administration of activated charcoal. Qf Med 1986;61:997-1002.

28 Weidle PJ, Skiest DJ, Forrest A. Multiple-dose activated charcoal as adjunct therapy after chronic phenytoin intoxication. Clin Pharm 1991;10:71-4.

29 Sessler CN, Glauser FL, Cooper KR. Treatment of theophylline toxicity with oral activated harcoal. Chest 1985;87:325-9.

30 Hillman RJ, Prescott LF. Treatment of salicylate poisoning with repeated oral charcoal. $B M \mathcal{J}$ 1985;291:1472.

31 Ilett KF, Hackett LP, Dusci LJ, Paterson JW. Disposition of dothiepin after overdose: effects of repeated-dose activated charcoal. Ther Drug Monit 1991;13:485-9.

\title{
The cervical spine in rheumatoid arthritis
}

\author{
Needs careful assessment
}

Rheumatoid arthritis commonly affects the cervical spine, causing several well defined deformities. ${ }^{1}$ Damage to the cervical spine from rheumatoid arthritis has been noted in $30 \%$ to $46 \%$ of necropsy studies and is second in frequency only to that seen in the metatarsophalangeal joints. ${ }^{23}$ One in four inpatients with rheumatoid arthritis and between $17 \%$ and $86 \%$ of all patients with this disease have radiological evidence of instability of the cervical spine. ${ }^{3-6}$

These high rates reflect the anatomy of the cervical spine and the dynamic forces that act on it. Each of the apophysial and ligamentous articulations of the cervical spine is susceptible to the same inflammatory changes as those in peripheral joints of patients with rheumatoid arthritis. ${ }^{2}$ Furthermore, the cervical spine is constrained between a somewhat rigid thoracic spine and a skull weighing $6 \mathrm{~kg}$; movement of the head, which has been estimated to occur around 600 times each hour, adds to the forces on the articulations.

Any segment of the cervical spine may be affected by the rheumatoid inflammatory process, but destructive changes are most prominent at the occipitoatlantoaxial junction. Atlantoaxial subluxation is the most common deformity and is due to destruction and resultant laxity of the transverse ligament. This allows the atlas to move forward relative to the odontoid process of the axis when the neck is flexed. In radiographs this is seen as a widening of more than $3 \mathrm{~mm}$ in the space between the anterior arch of $\mathrm{C} 1$ and the odontoid. The corresponding reduction in the space posteriorly restricts the canal available for the spinal cord. By contrast, posterior subluxation of the atlas is infrequent and is seen only in the presence of severe erosion and dislocation of the odontoid. ${ }^{8}$

Recent studies using magnetic resonance imaging in patients with atlantoaxial subluxation have shown an inflammatory mass of granulation tissue around the odontoid arising from the synovial lining of the articulations. This periodontoid mass is not visible in patients who have had surgical fusion of the first two cervical vertebrae or in whom deformity has progressed to that of atlantoaxial impaction (see below). ${ }^{910}$ The bulging of this mass may further reduce the space available for the spinal cord and cause neurological deficits in patients with only a moderate degree of atlantoaxial subluxation.

When the disease affects one of the occipitoatlantoaxial articulations (termed lateral mass) it may produce the syndrome of non-reducible rotational tilt of the head, the main clinical features of which are occipital pain, tender points in 
the neck, and tilting of the head towards the affected side. ${ }^{11}$ If both sides are affected collapse of the lateral masses allows the skull to descend on to the cervical spine and the odontoid to enter the foramen magnum. This deformity has been termed cranial settling, superior migration of the odontoid, or atlantoaxial impaction and is seen almost exclusively in association with atlantoaxial subluxation..$^{6812}$ Subaxial subluxation is a late development; it often affects several vertebrae, leading to a "stepladder" deformity. Extensive rheumatoid disease of the cervical spine results, then, in a combined deformity of atlantoaxial subluxation-subaxial subluxation and atlantoaxial impaction-a devastating complication and a truly formidable therapeutic challenge.

Deformities of the cervical spine are seen most often in patients with rheumatoid arthritis of more than 10 years' duration. They are usually associated with severe destructive peripheral arthritis, rheumatoid nodules, a high titre of rheumatoid factor, and treatment with corticosteroids. ${ }^{611}$ Progression of the deformity is unpredictable in a given patient, but follow up for five to 10 years has shown worsening of the instability in $16 \%$ to $41 \%$ of the patients. ${ }^{6812}$ These percentages may be too low: with progression of the deformity to atlantoaxial impaction the magnitude of the atlantoaxial subluxation may seem on radiography to be reduced, giving the false impression radiologically of improvement. ${ }^{12}$

Many patients with rheumatoid disease of the cervical spine remain asymptomatic for years, but they are at risk of a range of neurological complications and even sudden death from medullary compression. Neurological abnormalities may be subtle and difficult to establish in the presence of deforming arthritis, muscular atrophy, and the neuropathy that may be associated with rheumatoid arthritis. Patients may complain of intractable pain in the neck or the back of the head. They may have symptoms of vertebrobasilar insufficiency with vertigo or drop attacks and may have signs of myelopathy..$^{1314}$ Myelopathy, once it develops, is usually rapidly progressive. In patients with subaxial subluxation myelopathy may occur with only slight subluxation because of the narrower diameter of the spinal canal below the axis. Profound and complex neurological deficits may be found in patients with the combined deformity of atlantoaxial subluxation - subaxial subluxation-atlantoaxial impaction. Atlantoaxial subluxation with subluxation of less than $9 \mathrm{~mm}$ carries the least risk of neurological damage, while atlantoaxial subluxation of more than $9 \mathrm{~mm}$, atlantoaxial impaction, subaxial subluxation, non-reducible rotational tilt of the head, and combined deformities are all associated with a higher risk of neurological deficit. ${ }^{815}$

Plain radiographs of the cervical spine in flexion and extension will allow recognition of atlantoaxial subluxation and subaxial subluxation. In patients with atlantoaxial impaction, however, odontoid erosion and osteoporosis may make plain radiographs inadequate for assessing the extent of cranial settling and resultant penetration of the odontoid into the foramen magnum. Various measurements have been advocated to define the extent of cranial settling. McGregor's line, which assesses the protrusion of the odontoid process above the foramen magnum, is widely used in clinical practice. Because of its superior contrast capabilities magnetic resonance imaging is the current first choice technique for assessing instability of the cervical spine. ${ }^{1617}$

Patients with a minor degree of atlantoaxial subluxation or with subaxial subluxation need treatment only with a soft cervical collar-which provides symptomatic relief, acts as a reminder to patient and doctor, and may provide some degree of protection from trauma. In the presence of intractable cervical pain, neurological deficits, or myelopathy, or combinations of these, the recommended procedures are halo stabilisation and surgical arthrodesis. The place of surgery in the early stages of instability of the cervical spine is less certain, nor is there any consensus on whether progression can be retarded by early surgery. In a retrospective study of 110 patients with rheumatoid arthritis who had surgical treatment we found recurrence of their cervical instability after a mean interval of nine years in $5.5 \%$ of patients with atlantoaxial subluxation who required only atlantoaxial fusion -but a $36 \%$ recurrence rate after a mean interval of 2.6 years in patients with atlantoaxial subluxation and atlantoaxial impaction who required fusion from the occiput to $C 3$. No patient with atlantoaxial subluxation and fusion of $\mathrm{C} 1$ and $\mathrm{C} 2$ progressed to develop atlantoaxial impaction..$^{14} 18$

Many patients with substantial deformities remain asymptomatic, but they are at increased risk of neurological damage with the passage of time. They are also at risk if they need surgery or induction of anaesthesia for any other reason. In one recent study $60 \%$ of patients with rheumatoid arthritis having total hip or knee replacements had radiological evidence of instability of their cervical spine, and nearly half of these had no symptoms referrable to their necks. ${ }^{19}$ Patients with rheumatoid arthritis undergoing any major surgical procedure should be assessed by having radiographs taken of the cervical spine in flexion and extension. Indeed, all patients with rheumatoid disease of the necks, even though asymptomatic, should be followed up carefully for evidence of neurological deficit, and all should undergo periodic radiographic monitoring.

\section{Medical Center,}

Beaver, PA 15009

USA

Central Pennsylvania Orthopedic and

Spinal Associates,

Harrisburg, PA 17109

St Margaret Memorial Hospital,

DAVID R KRAUS

Pittsburgh, PA 15215

The University of Pittsburgh,

CARL H EISENBEIS Jr

Pittsburgh, PA 15215

1 Bland JH, Rheumatoid arthritis of the cervical spine. $\mathcal{F}$ Rheumatol 1974;1:319-42.

2 Eulderink F, Meijers KA. Pathology of the cervical spine in rheumatoid arthritis: a controlled study of 44 spines. F Pathol 1976;120:91-108.

3 Bland JH, Davis PH, London MG, VanBuskirk FW, Duarte CG. Rheumatoid arthritis of cervical spine. Arch Intern Med 1963;112:130-6.

4 Conlon PW, Isdale IC, Rose BS. Rheumatoid arthritis of the cervical spine-an analysis of 333 cases. Ann Rheum Dis 1966;25:120-6.

5 Meikle JA, Wilkinson M. Rheumatoid involvement of the cervical spine. Radiological assessment. Ann Rheum Dis 1971;30:154-61.

6 Smith PH, Benn RT, Sharp J. Natural history of rheumatoid cervical luxations. Ann Rheum Dis 1972;31:431-9.

7 Konttinen YT, Santavirta S, Kauppi M, Moskovich R. The rheumatoid cervical spine. Current Opinion in Rheumatology 1991;3:429-40.

8 Weissman BN, Aliabadi P, Weinfeld MS, Thomas WH, Sosman JL. Prognostic features of atlantoaxial subluxation in rheumatoid arthritis patients. Radiology 1982;144:745-51.

9 Larsson EM, Holtas S, Zygmunt S. Pre- and postoperative MR imaging of the craniocervical junction in rheumatoid arthritis. $A J R$ 1989;152:561-6.

10 Milbrink J, Nyman R. Posterior stabilization of the cervical spine in rheumatoid arthritis: clinical results and magnetic resonance imaging correlation. Fournal of Spinal Disorders 1990;3:308-15.

11 Halla JT, Hardin JG Jr. The spectrum of atlantoaxial facet joint involvement in rheumatoid arthritis. Arthritis Rheum 1990;33:325-9.

12 Matthews JA. Atlanto-axial subluxation in rheumatoid arthritis. A 5-year follow-up study. Ann Rheum Dis 1974;33:526-31.

13 Nakano KK. Neurological complications of rheumatoid arthritis. Orthopedic Clinics of North America 1975;6:861-80.

14 Kraus DR, Peppelman WC, Agarwal AK, De Leuw HW, Donaldson WF III. Incidence of subaxial subluxation in patients in generalized rheumatoid arthritis who have had previous occipital subluxation in patients in generalized rheumat
cervical fusions. Spine 1991;16(suppl):S486-9.

15 Agarwal AK, Kraus DR, Eisenbeis CH Jr, Stolzer BL, Balk PM, Barkley TA. Anatomical and neurological characteristic of cervical spine involvement in rheumatoid arthrits. $\mathcal{f}$ Orhop Rheumatol 1989;2:77-89.

16 Kauppi M, Sakaguchi M, Konttinen YT, Hamalainen M. A new method of screening for vertical atlantoaxial dislocation. $\mathcal{F}$ Rheumatol 1990;17:167-72.

17 Bell GR, Stearns KL. Flexion-extension MRI of the upper rheumatoid cervical spine. Orthopedics 1991;14:969-73.

18 Agarwal AK, Peppelman WC, Kraus DR, Pollock B, Stolzer BL, Eisenbeis CH, et al. Recurrence of cervical spine instability in rheumatoid arthritis following previous fusion: can disease progression be prevented by early surgery? I Rheumatol 1992;19:1364-70.

19 Collins DN, Barnes CL, FitzRandolph RL. Cervical spine instability in theumatoid patients having total hip or knee arthroplasty. Clinical Orhopedics and Related Research 1991;272:127-35. 